\title{
EFFECT OF INTANGIBLE ASSETS ON VALUE RELEVANCE: EVIDENCE FROM LISTED MANUFACTURING FIRMS IN NIGERIA
}

\author{
Ephraim Oryina, Mue ${ }^{1}$ and Salami Suleiman ${ }^{2+}$ \\ ${ }^{1,2}$ Ahmadu Bello University, Zaria, Nigeria \\ + Corresponding author: suleiman_salami@yahoo.com
}

\begin{abstract}
The increasing importance and role of intangible assets in today's economic environment is a source of concern for scholars and accounting practitioners. As an attempt to explore the relevance of reported intangible assets, the study investigated the market value relevance of different intangible asset (intellectual properties, computer software cost, and goodwill) reported by listed manufacturing firms in Nigeria. To achieve the research objective, the study adopted a correlational research design. The study utilized secondary data extracted from the annual reports and accounts of manufacturing firms listed on the Nigerian stock exchange. The study concentrated on firms that reported components of intangible assets for six years (2013-2019). The model was estimated using the random effect regression technique. The findings revealed intellectual properties to be positively and significantly associated with the market value of listed manufacturing firms in Nigeria. However, goodwill was shown to have a negative and significant relationship with market value. Based on the findings, the study recommends, amongst others, that the management of manufacturing firms bring their expertise to develop innovative technologies and business adaptations, as well as direct policies that will improve brand names and trademarks and protect patents and other intellectual properties as they will impact the market price.
\end{abstract}

Keywords. Intangible assets: intellectual properties: goodwill: market value: computer software asset

JEL Codes. G3; M21; H81.

Received 10th January 20. Revised 3rd April 20. Accepted 19th April 20.

\section{Introduction}

Intangibles like computer software are becoming more relevant than ever before, especially as they aid the computerization of inventory management and production process in the manufacturing sector. Another intangible asset relating to manufacturing firms is intellectual properties. The growth in the information age was borne out of the interplay of intellectual properties, which Greenhalgh and Rogers (2007) opined as a policy tool for encouraging innovation. Another intangible asset relating to manufacturing firms is the purchased goodwill. The changing economic environment of the 1980s aligned to a large merger wave, thereby increasing the amount of goodwill on a company's audited financial statements. Therefore, there is a growing need by firms to evaluate their investment in intangible assets to gauge their effect on the market value.

With the growth in intangible assets and their effect on the market value, intangible assets are beginning to receive a renewed vigor amongst scholars and practitioners. An investigation by Barnes (2010) found that intangible assets are likely to be more critical in some industries than in others. They further opined that the amount of intangibles is growing bigger in the manufacturing 
sectors than the services sector. This was corroborated by the latest economic report by Renaissance Capital (Oladunjoye, 2016). The report reveals that the Nigerian manufacturing sector is now the major driver of economic growth in Nigeria. According to the report, with Nigeria's rebased Gross Domestic Product (GDP), the manufacturing sector is currently growing faster than the telecommunications, oil \& gas, and agricultural sectors. The report further states that recent figures by the Manufacturers Association of Nigeria showed an increase in manufacturing capacity utilization from 46.3 percent recorded in the first half of 2013 to 52.7 percent in the second half of the same year.

A few studies have examined the value relevance of such aspect of intangibles in the market valuation of companies in Nigeria (Abubakar \& Abubakar, 2015; Nnado \& Ozouli, 2016). These studies showed a relationship between intangible asset and firm value. However, none of them has fully exposed how the categories of intangibles, such as computer software, intellectual property, and goodwill, can serve as a signaling device to changes in the share price. Thus, the present study examined the effect of comprehensive disclosure of intangible assets on the share price of manufacturing firms in Nigeria.

We adopted the signaling theory to contend that firms reporting intangible assets in their financial statements have increased market price per share. This study has both policy and theoretical contributions. We contribute to the extant literature on the relationship between intangible assets and share price. This study found that computer software and intellectual property have a positive influence on the share price. Thus, as firms increase investments in computer software and intellectual property, positive signals are sent to the market, which increases the share price. As part of policy contribution, the management of manufacturing firms can bring their expertise to develop innovative technologies and business adaptations, as well as direct policies that will improve brand names and trademarks and protect patents and other intellectual properties, as they will impact the market price.

Academics, regulators and practitioners have argued in favor of the inclusion of some of these intangibles in the statement of financial position as their non-inclusion may lead to the deterioration of the quality of accounting information as evident in the increasing gap between book values and market values of firms (Abubakar, 2014). Furthermore, related studies in Nigeria (Dogara, 2013; Omoye, 2013) have concentrated on the determinants of intangible assets disclosure and the effect of expensed intangibles (branding cost) on market value. Researchers in Nigeria have failed to study the distinct elements of the intangible assets (computer software, intellectual properties, and goodwill), which this study intended to investigate.

\section{Literature Review and Hypothesis Development}

The effect of intangible assets on the value relevance of accounting information has been studied widely. While research in this area abounds mostly in Europe and the United States, studies in Nigeria are just beginning to extend their interest to this area. This could be due to the developments in the new economy, which emphasizes innovation and technological advancement, and the adoption of a global accounting standard, which highlights the importance of intangible assets disclosure and its value relevance. 
In their study of the relationship between computer software and the market value of a sample of 128 metal companies listed on the Tehran Stock Exchange for the period 2001 to 2011, Behname, Pajoohi and Ghahramanizady (2012) reported that computer software assets have a significant positive relationship with market value. By employing the pooled/panel regression method and FLimer, they concluded that an increase in computer software assets leads to a rise in the market value of companies in this industry. The use of a large sample size of 128 firms was considered appropriate; however, its focus was on foreign firms. This is because firms listed on the Tehran Stock Exchange operate in a different economic, social and political environment as compared to manufacturing firms in Nigeria. For this reason, the findings arrived might not apply to the Nigerian firms in general and the manufacturing firms in particular.

Min (2012) explored the value relevance of capitalized software expenditure reported by 5242 firm-years of firms listed on the Korean Stock Exchange from 2001 to 2010 by using the popular Ohlson (1995) framework. The result indicated that software expenditure had a positive association with the market value of firms. When this analysis was extended to the different industries, some intangible assets in the technology firms were found to be more value relevant than in other industries. Although the study is relatively recent, and a good number of variables of intangible assets were captured, the socio-economic characteristics of the domain are quite distinct from the Nigerian environment. Thus, the findings may not apply to Nigerian firms in general and the manufacturing firms in particular.

Oliviera, Rodrigues, and Craig (2010) assessed the value relevance of computer software cost using a sample of non-financial firms listed on the Portuguese Stock Exchange from 1998 to 2008. They used panel data to study the impact on the value relevance of Portugal's formal adoption of IAS/IFRS in 2005. They found that reported intangibles, such as computer software cost, are highly significantly associated with stock prices. However, the change to IAS/IFRS was found to have no significant impact on the value relevance of computer software after the post-adoption era.

$\mathrm{H}_{\mathrm{O} 1}$ : Computer software assets have no significant effect on the market value of listed manufacturing firms in Nigeria.

$\mathrm{H}_{1}$ : Computer software assets have a significant effect on the market value of listed manufacturing firms in Nigeria.

Using a sample of 2,042 and 2,289 firm-years in Malaysia public-listed firms in pre-IFRS (2002 to 2005) and post-IFRS (2008 to 2011) period, Jaafar and Halim (2013) examined the relationship between accounting choice for intangible assets (brand names, patents and trademarks, licenses, copyrights, and designs) and their value relevance, as well as the moderating effect of firm life cycle on this relationship. By using regression analysis, the findings indicated that during the preIFRS period, capitalized identifiable intangible assets were value relevant. A comparison between the pre- and post-IFRS period suggested that the market attaches higher value relevance to identifiable intangible assets after the adoption of IFRS. The study classified the sampled firms into three life cycle stages: Growth, Mature, and Decline. This suggests that a firm, at different stages of its life cycle, can be valued differently, depending on the relative proportion of its assets and growth opportunities. The pitfall in the study is mostly attributable to the difficulties in operationalizing the life cycle concept, which is closely related to the lack of specific measures 
used to classify firms into life cycle stages. The varying number of stages also means that studies have to deal with issues, such as the model or number of stages that best reflect the development of a firm, since not all firms evolve through the same life-cycle stages.

A similar study by Jaafar (2011) examined the moderation effect of firm life cycle on the relationship between accounting choice for intangible assets (brand names, patents and trademarks, licenses, copyrights, and designs) and their value relevance in the pre- and post-Australian Equivalents to International Financial Reporting Standards (AIFRS) periods. The sample consisted of 900 and 1,225 firm-years observations for the pre- and post-AIFRS period, respectively, with sample firms classified into three life cycle stages: Growth, Mature, and Decline. The findings indicated that during the pre-AIFRS period, intellectual property assets were value relevant. A comparison between the pre- and post-AIFRS period suggests that the market attaches a higher value to identifiable intangible assets after the adoption of AIFRS. This study, although relevant, has findings too specific to different stages of a firm's life-cycle. As a result, the finding may be difficult to apply to manufacturing firms in Nigeria.

Ho2: Intellectual properties have no significant effect on the market value of listed manufacturing firms in Nigeria.

$\mathrm{H}_{2}$ : Intellectual properties have a significant effect on the market value of listed manufacturing firms in Nigeria.

Min (2012) explored the value relevance of goodwill by Korean firms. The result indicated that goodwill was negatively associated with stock prices. When this analysis was extended to different industries, some intangible assets were found to be more value relevant for information technology firms and some to be less value relevant.

Istrate (2013) demonstrated that the amount of goodwill was significantly related to market value, but the relevance of goodwill did not increase in the post-adoption period. Chalmers, Clinch, and Godfrey (2008) compared the Australian GAAP and IFRS balances for goodwill reported in the annual reports. The results provided partial support for IFRS-measured goodwill being incrementally value relevant to that conveyed under Australian GAAP. It was hypothesized that:

Ho3: Goodwill has no significant effect on the market value of listed manufacturing firms in Nigeria.

$\mathrm{H}_{3}$ : Goodwill has a significant effect on the market value of listed manufacturing firms in Nigeria.

The theory that can be considered relevant in explaining how investment in intangible assets influences market price is the signaling theory. According to Spence (2002), the signaling theory originated out of the idea of information asymmetry. He further opined that firms could get around the problem of asymmetric information by sending signals that would reveal pieces of relevant information to the investor. Comprehensive disclosure of intangible assets in the financial statement can enhance the information quality of the financial statement. This can also boost the book value and other accounting measures of a firm. Investors can thus interpret the signal and make decisions by offering a higher price than when the signal has not been received. 
Khanagha (2011) opined that the value investors place on the quality of accounting information is determined by how well it meets their needs. Published information will signal to investors the type of investment decision to make. The market reacts either positively or negatively when the information content impacts on accounting measures. Intangible assets, such as goodwill, trademarks, and patents, can serve as a signaling device by changing the volume of stock trading, which can, in turn, impact on the share price.

\section{Methodology, Sample, and Data}

This study adopted a correlational research design. This is consistent with the main objective of the correlation design, which is to investigate the relationship among the variables of a study. In other words, a correlational design is associated with scientific, experimental, quantitative and deductive frameworks where researchers seek specific, quantifiable observations by the use of statistics and experiments to test hypotheses (Habbash, 2010). In this study, accounting variables and identifiable intangible assets were regressed against market price to understand their value relevance on accounting information. Therefore, this design assists in evaluating whether or not an accounting variable is deemed value relevant if its coefficients is statistically significant, thus reflecting information that is relevant to investors (Barth, 2000; Barth et al., 2001). Moreover, this design is consistent with other value relevance studies of accounting information (Istrate, 2013; Jafar \& Halim, 2013).

The population of this study comprised manufacturing firms that reported intangible assets in their financial statements within the study period. These were firms listed on the floor of the Nigerian Stock Exchange (NSE) as at 31st December 2019. Therefore, in arriving at the population of the study, only 34 firms that reported components of intangibles to include computer software, intellectual property, and goodwill in their financial statement during the period under review (2013 - 2019) were considered. As a result, a total of nine manufacturing firms that consistently reported components of intangible assets on their financial statement were covered by the study.

The data for this study were obtained from secondary sources because the estimation of the model adopted in the study requires the use of quantitative data. Consequently, data on computer software, intellectual property, goodwill, book value, earnings, and dividend were extracted from the annual reports and accounts of companies retrieved from the official website of the studied firms and the website of the NSE.

To examine the effect of value relevance on intangible assets of manufacturing firms in Nigeria, multiple regression analysis was used as the major technique of data analysis. Multiple regression analysis was adopted for the study because of its ability to predict and explain the expected variation in value relevance as a result of intangible assets. The choice of the appropriate multiple regression techniques was, however, dependent on the nature of data to be analyzed. Consequently, the analysis was carried out within a panel data estimation framework. Panel data estimation allows for the control of individual-specific effects usually unobservable which may be correlated with other explanatory variables included in the specification of the relationship between dependent is explanatory variables (Hausman \& Taylor, 1981). The preference of this estimation method was not only because it enables a cross-sectional time-series analysis, which usually makes provision for a broader set of data points, but also because of its ability to control for heterogeneity issues. 
The regression model was employed to test the hypothesis, which states that intangible asset components have no significant effect on the market value of manufacturing firms in Nigeria. This study is consistent with related studies on the value relevance of intangible assets which used earnings, book values, and dividend as control variables. Therefore, the value relevance of intangible assets is presented in the form of a regression equation. Specifically, the model of the study is written as follows:

$$
M V S_{i t}=\alpha+\beta_{1} C S S_{i t}+\beta_{2} I P S_{i t}+\beta_{3} G P S_{i t}+\beta_{4} B V S_{i t}+\beta_{5} E P S_{i t}+\beta_{6} D P S_{i t}+\varepsilon_{i t}
$$

where $\mathrm{MVS}_{\mathrm{it}}=$ market value per share of firm $i$ in year $t, 120$ days after the accounting date. The 120 days window is necessary because of the weak form of the Nigerian capital market and to ensure that all available information is reflected in the stock price. Moreover, most firms in Nigeria release their end of year financial statements by March or April of the following year. This implies that by 120 days, all available information must have been fully reflected in the stock price.

$\mathrm{CSS}_{i t}=$ computer software cost per share of firm $i$ at the end of year $t$;

IPS $_{i t}=$ intellectual property cost per share of firm $i$ at the end of year $t$;

$\mathrm{GPS}_{i t}=$ goodwill per share of firm $i$ at the end of year $t$;

$\mathrm{BVS}_{i t}=$ book value of equity per share of firm $i$ at the end of year $t$;

$\mathrm{EPS}_{i t}=$ earnings per share of firm $i$ at the end of year $t$;

DPS $_{i t}=$ dividend per share of firm $i$ at the end of year $t$;

$e_{i t}$ is the error term used as surrogate for all other variables not included;

$\alpha$ is the intercept or constant;

All variables were scaled by the number of outstanding ordinary shares, as applied in many of previous studies, such as Abubakar and Abubakar (2015), Ritter and Wells (2006), and Zhao (2002). If these variables were scaled by total assets, the output for computer software, intellectual property, and goodwill would be zero, leading to a negative statistical consequence on the outcome of the result. The measurement of the variables used in the study is presented in Table 1.

Table 1: Variables Definition and Measurement

\begin{tabular}{|l|l|}
\hline \multicolumn{1}{|c|}{ Variables } & \multicolumn{1}{c|}{ Definition and Measurement } \\
\hline Market Value Per Share (MVS) & $\begin{array}{l}\text { Measured as the stock price of the firm's shares 120 days } \\
\text { after the accounting date (Mackinlay, 1997). This is because } \\
\text { the weak form of Nigeria's capital market is in its semi- } \\
\text { strong or even weak form, and that after the 120 days } \\
\text { window, all available information must have been fully } \\
\text { reflected in the stock price. }\end{array}$ \\
\hline Book Value Per Share (BVS) & $\begin{array}{l}\text { Measured as the value of common equity divided by the } \\
\text { number of ordinary shares (Aboody \& Lev, 1998). }\end{array}$ \\
\hline Earnings Per Share (EPS) & $\begin{array}{l}\text { Measured by dividing profit or loss attributable to ordinary } \\
\text { equity holders by the number of ordinary shares (Aboody \& } \\
\text { Lev, 1998). }\end{array}$ \\
\hline Dividend Per Share (DPS) & $\begin{array}{l}\text { Measured by dividing the total dividend attributable to } \\
\text { ordinary equity holders by the number of ordinary shares } \\
\text { (Masum, 2014). }\end{array}$ \\
\hline
\end{tabular}




\begin{tabular}{|l|l|}
\hline $\begin{array}{l}\text { Computer Software Cost Per } \\
\text { Share (CSS) }\end{array}$ & $\begin{array}{l}\text { Measured as the cost of computer software divided by the } \\
\text { number of ordinary shares (Min, 2012; Aboody \& Lev, } \\
\text { 1998). }\end{array}$ \\
\hline $\begin{array}{l}\text { Intellectual Properties Cost Per } \\
\text { Share (IPS) }\end{array}$ & $\begin{array}{l}\text { Measured as the cost of intellectual properties (patents, } \\
\text { trademarks, designs, licenses, brands and copyrights) } \\
\text { divided the number of ordinary shares (Min, 2012). }\end{array}$ \\
\hline Goodwill Per Share (GPS) & $\begin{array}{l}\text { Measured as the value of goodwill divided by the number of } \\
\text { ordinary shares (Istrate, 2013; Min, 2012). }\end{array}$ \\
\hline
\end{tabular}

Note: $\beta_{1}$, to $\beta_{6}$ are the coefficient of the parameter estimates.

\section{Results and Discussion}

The descriptive statistics for each variable that shows the minimum, maximum, mean, standard deviation, skewness, and kurtosis are presented in Table 2.

Table 2: Descriptive Statistics

\begin{tabular}{lllrllll}
\hline \multicolumn{1}{c}{ Variables } & \multicolumn{1}{c}{ Mean } & \multicolumn{1}{c}{ Std. Div } & Min & \multicolumn{1}{c}{ Max } & Skewness & Kurtosis & N \\
\hline MVS & 56.0092 & 63.6275 & 0.5200 & 265.28 & 1.3088 & 4.1482 & 63 \\
CSS & 0.1752 & 0.2387 & 0.0002 & 1.3072 & 2.2010 & 9.5085 & 63 \\
IPS2 & 0.8950 & 1.5011 & 0.0004 & 7.8328 & 2.4186 & 9.4405 & 63 \\
GPS & 2.3062 & 5.3309 & 0.0017 & 35.8761 & 4.4236 & 26.4628 & 63 \\
BVS & 16.8352 & 14.3363 & 0.0019 & 39.8079 & 0.3322 & 1.4684 & 63 \\
EPS & 5.6847 & 8.8956 & -6.296 & 54.29 & 3.30042 & 16.6335 & 63 \\
DPS & 1.8154 & 2.3965 & 0.02 & 10.000 & 1.9643 & 6.3228 & 63 \\
\hline
\end{tabular}

Table 2 presents the descriptive statistics for the dependent variable (Market Value per Share $=$ MVS) and the independent variables (Computer Software per Share $=$ CSS, Intellectual Property per Share=IPS, Goodwill per Share $=$ GPS, Book Value per Share=BVS, Earnings per Share $=$ EPS, and Dividend per Share $=$ DPS). From the table, the mean of Market Value per Share (MVS) was 56.0092 with a standard deviation of 63.6275, which implies that, on average, for each share issued by the firms, the market price is N56.0092 during the period of the study. There was also a wide dispersion of data from the mean because of the high standard deviation over the mean. The result also showed a relatively impressive high share price of N265.28 and a minimum of N0.52 during the study period. The results of the skewness and kurtosis indicated that the data (MVS) were not normally distributed.

Also shown was the minimum CSS and IPS of 0.0002 and 0.0004 , respectively, while their maximum being 1.3072 and 7.8372, respectively. This implies that investment or recognition of computer software assets and intellectual properties by manufacturing firms is very low relative to the number of outstanding shares. The mean values of CSS and IPS were 0.1752 and 0.8952 , respectively, indicating that, on average, the computer software and intellectual properties to share ratio are N0.17 and N0.89, respectively. On the other hand, their standard deviation of 0.2387 and 1.5011 imply high dispersion of the data from their respective mean.

Table 2 also shows the mean and standard deviation of GPS to be 2.3062 and 5.3309, respectively, while the minimum and maximum values stood at 0.0017 and 35.8761 , respectively. BVS, EPS, and DPS return a mean of 16.8352, 5.6847 and 1.8154, respectively, with a standard deviation of 
$14.3363,8.8956$, and 2.3965 , respectively. The result showed high volatility of the dataset. The minimum value of EPS is -6.296 , which suggests that some manufacturing firms made losses during the period of the study. On the other hand, the maximum DPS is 10 . This suggests that one of the manufacturing firms paid a dividend of N10 per share during the study period. This is not unlikely, especially for big manufacturing firms like Guinness.

The result of skewness and kurtosis showed that, to a large extent, the dataset was not normally distributed, as the values were greater than zero. The variables of the study were further subjected to Shapiro-Wilk (W) test for data normality. The technique tests the null hypothesis that the variables are normally distributed. The result of the normality test of the variables is presented in Table 3 .

Table 3: Result of the Shapiro Wilk Normality Test

\begin{tabular}{crrrrc}
\hline Variables & $\operatorname{Pr}($ Skewness) & $\operatorname{Pr}$ (Kurtosis) & adj chi2 & Joint ProbZ & Observation \\
\hline MVS & 0.0001 & 0.0631 & 14.21 & $<0.001$ & 63 \\
CSS & 0.0000 & 0.0000 & 33.19 & $<0.001$ & 63 \\
IPS & 0.0000 & 0.0000 & 35.23 & $<0.001$ & 63 \\
GPS & 0.0000 & 0.0000 & 63.79 & $<0.001$ & 63 \\
BVS & 0.2473 & 0.0000 & 57.87 & $<0.001$ & 63 \\
EPS & 0.0000 & 0.0000 & 49.86 & $<0.001$ & 63 \\
DPS & 0.0000 & 0.0012 & 25.89 & $<0.001$ & 63 \\
\hline
\end{tabular}

Table 3 indicates that the p-values were all significant at $1 \%$. Thus, the hypothesis that the data are normally distributed was rejected. This confirmed the hypothesis that the data for all the variables of the study were not normally distributed. The non-normality of data were generally associated with panel data and will not, in any way, affect the reliability of the result estimates.

\section{Correlation Analysis}

The correlation matrix explains the relationship between the dependent and independent variables and also the relationship between the independent variables themselves. Table 4 presents the correlation matrix of the study.

Table 4: Correlation Matrix

\begin{tabular}{llllllll}
\hline Variables & MVS & CSS & IPS & GPS & BVS & EPS & DPS \\
\hline MVS & 1.0000 & & & & & & \\
CSS & 0.3277 & 1.0000 & & & & & \\
IPS & 0.3266 & 0.1755 & 1.0000 & & & & \\
GPS & 0.1301 & -0.0114 & 0.4212 & 1.0000 & & & \\
BVS & 0.3807 & 0.3474 & 0.1218 & 0.0966 & 1.0000 & & \\
EPS & -0.0200 & -0.1713 & -0.0846 & -0.0972 & -0.0380 & 1.0000 & \\
DPS & 0.8566 & 0.2288 & 0.3354 & 0.2207 & 0.1164 & -0.0535 & 1.0000 \\
\hline
\end{tabular}


The correlation matrix shows that market value was positively correlated with all the independent variables of the study. This implies that an increase in the market price per share will result in an increase in the value of computer software, intellectual property, goodwill, book value, earnings, and dividend of listed manufacturing firms in Nigeria, as the association was positive. However, the relationship between market value per share and dividend was the highest (0.8566). This goes to show the extent to which market price is explained by dividend payment.

Table 4 also reveals the relationship between the independent variables themselves. Computer software was negatively correlated with goodwill and earnings at -0.0114 and -0.1713 , respectively. This shows that as the value of computer software decreases, the value of the firms' goodwill and earnings increase. More so, there was a negative association between earnings with computer software, intellectual properties, goodwill, and book values. This indicates that as earnings decrease, all these other variables increase in a corresponding manner.

\section{Presentation and Interpretation of Regression Results}

Table 5 summarizes the regression results as captured in the model of the study $M V S_{i t}=\alpha+$ $\beta_{1} B V S_{i t}+\beta_{2} E P S_{i t}+\beta_{3} D P S_{i t}+\beta_{4} C S S_{i t}+\beta_{5} I P S_{i t}+\beta_{6} G P S_{i t}+\varepsilon_{i t}$

Table 5: Summary of Regression

\begin{tabular}{lrrrrr}
\hline Variables & Coefficient & z-statistics & z-sig. & VIF & TV \\
\hline Constant & 0.1035 & 0.02 & 0.987 & & \\
CSS & 26.7685 & 2.64 & 0.008 & 1.30 & 0.7715 \\
IPS & 5.8973 & 1.99 & 0.047 & 1.25 & 0.8020 \\
GPS & -2.6595 & -0.39 & 0.695 & 1.23 & 0.8143 \\
BVS & 0.4252 & 1.48 & 0.140 & 1.22 & 0.8193 \\
EPS & 0.3730 & 1.46 & 0.144 & 1.16 & 0.8612 \\
DPS & 20.6819 & 9.63 & 0.000 & 1.04 & 0.9538 \\
\hline R $^{2}$ Overall & & & 0.7783 & & \\
Wald Chi2 & & & 337.08 & & \\
Prob $>$ Chi2 & & & 0.000 & & \\
\hline
\end{tabular}

The result of multiple coefficients of determination $\left(\mathrm{R}^{2}\right)$ in Table 5 indicated that the independent variables (computer software, intellectual property, goodwill, book values, earnings and dividend) jointly explained about $77.83 \%$ of the total variation in the dependent variable (market value per share) of listed manufacturing firms in Nigeria. Other factors not captured in the model accounted for the remaining $22.17 \%$. Similarly, the result of the Wald $\mathrm{Chi}^{2}$ (337.08) showed that the model was fit at $1 \%$ significance ( $\mathrm{Prob}>\mathrm{Chi} 2=0.0000$ ), meaning that there is a $99.9 \%$ probability that the relationship among the variables of the study is not just due to mere chance.

Computer software per share had a coefficient of 26.7685, which indicates that it had a positive association with market price per share, as the p-significance value was 0.008 , which was statistically significant at $1 \%$. Computer software per share was found to have a positive and statistically insignificant association with market value. Therefore, the result indicated that computer software per share had a significant impact on the market value of listed manufacturing firms in Nigeria. The result provides evidence of failing to reject hypothesis 1 of the study. 
The statistically insignificant association of investment in computer software and the market value of listed manufacturing firms in Nigeria was contrary to expectation. This could be that the value of the investment in computer software is not significant as to have a positive influence on their share prices. In addition, due to the emergence of IAS 38, the reporting of certain categories of intangibles on the balance sheet has now been omitted (Jaafar, 2011). The result is consistent with the findings of Oliviera, Rodrigues, and Craig (2010) and Chalmers et al. (2008). However, it contradicts the findings of Min (2012), Behname et al. (2012), and Aboody and Lev (1998), who found a strong positive relationship between computer software cost and market value.

The coefficient of intellectual properties per share was 5.8973, while the $\mathrm{Z}$ statistics was significant at $5 \%(0.047)$. This indicates a positive relationship between intellectual properties and market value on the one hand and market value, on the other hand. The significant positive relationship between intellectual property and market value implies that as an investment in intellectual properties increases, the market value per share also increases. For every one-point increase in intellectual properties, share price increases by 5.8973 points. This, therefore, provides justification for rejecting hypothesis 2 of the study. This explains that recognizing intellectual property on the statement of financial position of listed manufacturing firms in Nigeria may result in an increase in the share prices of the firms. The result also supports the findings of Behname et al. (2012), Ritter and Wells (2006), Min (2012), Jaafar (2011), and Greenhalgh and Rogers (2007), who reported a significant positive association between intellectual property and market value. However, the result contradicts the findings of Istrate (2013) and Chalmers et al. (2008), who found no significant relationship between intellectual property and market value.

Goodwill per share was negatively related to market value per share as indicated by the coefficient of -2.6595 , which was statistically insignificant at all levels of significance. This indicates a negative relationship between goodwill and market value. The insignificant negative relationship between goodwill and market value implies that an increase in the value of goodwill may not necessarily decrease the market price. Goodwill per share was found to have a negative and statistically insignificant association with market value. The result provides justification for failing to reject hypothesis 3 of the study. The result showed that recognizing goodwill on the statement of financial position of listed manufacturing firms in Nigeria did not drive the share price of the firms. The significant value relevance of goodwill is not supported by the findings of Min (2012), Istrate (2013), Oliviera et al. (2010), and Chalmers et al. (2008), who found a significant relationship between goodwill and stock prices.

The coefficients of control variables of book value per share and earnings per share were 0.4252 and 0.3730 , respectively. The result confirmed their positive relationship with market value per share. The association was, however, not statistically significant, as the p-significance values were 0.140 and 0.144 , respectively. However, dividend per share was found to have a significant effect on share price given the coefficient value of 20.6819 , which was statistically significant at $1 \%$.

There are several policy implications of this study. Firstly, the management of manufacturing firms can bring their expertise to develop innovative technologies and business adaptations, as well as direct policies that will improve brand names and trademarks, protect patents, and other intellectual properties as they will impact on market price. Secondly, the findings imply that potential and 
existing investors are to consider manufacturing firms with high investment in intangible assets in making their investment decisions as this will maximize their share price. Thirdly, regulators should develop a better framework in accounting for the goodwill that will provide other accounting choices which may have serious negative consequences on future earnings and affect the market value of the firm's shares.

\section{Conclusion}

The study draws its conclusions based on the empirical and statistical evidence arrived at after analyzing and discussing the result using the independent variables to explain and predict the market value per share of the sampled manufacturing firms. Computer software is positively and statistically significantly related to market value. Investment in computer software increases the share price. It could be that manufacturing firms comprehensively report intangible assets on their balance sheet as stated in IAS 38 .

Intellectual property has a significant impact on market price per share. Thus, when the level of intellectual property is high, the share price of manufacturing firms will also go up. This may be as a result of the signaling effect that intellectual property plays in influencing investors' behavior as the positive signal created by trademarks, patents, copyrights, designs, and licenses has a positive effect on the share price of manufacturing firms. Goodwill is negatively associated with share price. One probable way to explain the negative association of goodwill is to assume that the signaling effect such business combinations or acquisitions might have on the stock prices may only be for a short term. Subsequent amortization of goodwill might not have a substantial impact on the association with market price as information may have doused down with a systematic decrease in the amount of reported goodwill.

\section{Limitations and Suggestions for Further Research}

Hardly is any study conducted without some research limitations. Firstly, there is the dearth of local literature regarding the individual components of intangible assets. This makes comparison of this study to others within our local setting difficult. Secondly, the findings of this study may not be generalizable to the excluded sectors (banks and insurance). The study is limited by small sample size and short time period. The sample size might be a limitation because of the nonavailability of data for all the companies. Moreover, some firms were deleted because they failed to pass the sample size selection criteria.

The dearth of empirical research on the value relevance of intangible assets of listed firms in Nigeria suggests that more studies are needed to provide additional insights into this issue. More so, the findings of this study are inconsistent with most of the findings in the developed economies. This is possibly due to the differences in socio-economic environment, the quality of reporting, and accessibility to huge volume of data. Thus, future research is open to other sectors and longer time periods as this may assist in ascertaining the trends in the change of value relevance of the intangible assets. Finally, future research could be conducted to evaluate the impact of intangible assets on other accounting measures, such as earnings, voluntary disclosure, and dividend payment. 


\section{References}

Aboody, D. \& Lev, B. (1998). The value relevance of intangibles: the case of software capitalization. Journal of Accounting Research, 36, 161-191.

Abubakar, M. (2014). Intangible assets recognition quality of accounting information of listed high-tech firms in Nigeria. An unpublished M.Sc Thesis. Department of Accounting, Ahmadu Bello University, Zaria.

Abubakar, S. \& Abubakar, M. (2015). Intangible assets and value relevance of accounting information of listed high-tech firms in Nigeria. Research Journal of Finance and Accounting, 6(11), 60-73

Barnes, P. (2010). Investments in intangible assets and Australia's productivity growth: sectorial estimates. Productivity Commission Staff Working Paper. Available at SSRN: https://ssrn.com/abstract $=1802854$

Barth, M.E. (2000). Valuation-based research for financial reporting and opportunities for future research. Accounting and Finance, 40 (2000), 7-31.

Barth, M., Beaver, W. H. \& Landsman, W. R. (2001). The relevance of the value relevance literature for financial accounting standard setting: Another view. Journal of Accounting and Economic, 31(1-3), 77-104.

Behname, M; Pajoohi, M.R. \& Ghahramanizady, M. (2012). The relationship between intangible assets and the market value; metals industry of Tehran stock exchange case study. Australian Journal of Basic and Applied Sciences, 6 (12), 115-122.

Chalmers, K., Clinch, G. \& Godfrey, J. (2008). Adoption of international financial reporting standards: impact on the value relevance of intangible assets. Australian Accounting Review, 18, 237-247.

Dogara, I.A. (2013). Intangible assets and the performance of deposit money banks in Nigeria. An unpublished M.Sc Thesis. Department of Accounting, Ahmadu Bello University, Zaria.

Greenhalgh, C. \& Rogers, M. (2007). The value of intellectual property rights to firms and society. Oxford Review of Economic Policy, 23(4), 541-567.

Habbash, A. (2010). Audit quality and earnings management: evidence from Jordan. Journal of Applied Accounting Research, 17 (2), 170-189.

Hausman, J. \& Taylor, W. (1981). Panel data and unobservable individual effects. Econometrica, 49(6), 377-398.

Istrate, R. (2013). IFRS adoption and the value relevance of goodwill and other intangible assets: U.K. empirical evidence. Amsterdam Business School. University of Amsterdam. Working paper.

Jaafar, H. (2011). Accounting for intangible assets, firm life cycle and the value relevance of intangible assets. An unpublished Ph.D. Dissertation, University of Tasmania.

Jaafar, H. \& Halim, H. A. (2013). Firm life cycle and the value relevance of intangible assets: the impact of IFRS 138 adoption. International Journal of Trade, Economics and Finance, 4(5), 252-258.

Khanagha, J. B. (2011). Value relevance of accounting information in the United Arab Emirates. International Journal of Economics and Financial Issues, 1(2), 33-45.

Mackinlay, A.C. (1997). Event studies in economics and finance. Journal of Economic Literature, 35, 13-39. 
Masum, A.A. (2014). Dividend policy and its impact on stock price - a study on commercial banks listed in Dhaka stock exchange. Global Disclosure of Economics and Business, 3 (1), 9-17

Min, H. (2012). The Value relevance of intangible assets in Korean Firms. An unpublished Master Thesis of the Faculty of Economics and Business Studies. Tilburg University.

Nnado, I.C and Ozouli C.N. (2016). Evaluating the effect of intangible assets on economic value added of selected manufacturing firms in Nigeria. European Journal of Business and Management. 8 (15), 174-181.

Ohlson, J.A. (1995). Earnings, Book Values, and Dividends in Equity Valuation. Contemporary Accounting Research, 11, 661-687.

Oladunjoye, P. (2016). Manufacturing sector now Nigeria's major economic growth driverrencap. Independent Newspapers Limited, 15th July 2014. Retrieved from http://dailyindependentnig.com/2014/07

Oliveira, L; Rodrigues, L.L. \& Craig, R. (2010). Intangible assets and value relevance: evidence from the Portuguese stock exchange. The British Accounting Review, 42, $241-252$.

Omoye, A.S. (2013). Determinants of intangibles assets disclosure in annual report: evidence from Nigerian quoted companies. International Journal of Asian Social Science, 3(5), 1152-1165.Retrieved from: http://www.aessweb.com/journaldetail.php?id=5007

Ritter, A. \& Wells, P. (2006). Identifiable intangible asset disclosure, stock prices and future earnings. Accounting and Finance, 46, 843-863.

Spence, M. (2002). Signaling in retrospect and informational structure of markets. American Economic Review, 92(3), 434-459.

Takacs, L. M. (2012). The value relevance of earnings in a transition economy: evidence from Romanian stock market. Annales Universitis Apulensis series Oeconomica, 14 (1), 88-103.

Zhao, R. (2002). Relative value relevance of R\&D reporting: an international comparison. Journal of International Financial Management and Accounting, 13(2), 153-174. 